\title{
Social Function of Small Business Taxes in Russia
}

\author{
Vladimir Vladimirovich Glukhov ${ }^{1}$, Egor Vladimirovich Glukhov ${ }^{1}$, Zhanna Ivanovna Lialina ${ }^{1}$, Vladimir \\ Anatolievich Ostanin ${ }^{1} \&$ Yuri Vladimirovich Rozhkov ${ }^{2}$ \\ ${ }^{1}$ Far Eastern Federal University, Russian Federation \\ ${ }^{2}$ Khabarovsk State Academy of Economics and Law, Tikhookeanskaya, Khabarovsk, Russian Federation \\ Correspondence: Vladimir Vladimirovich Glukhov, Sukhanova 8, Vladivostok, 690950, Russian Federation. \\ E-mail: gvv61@bk.ru
}

Received: February 2, 2015 Accepted: April 27, 2015 Online Published: July 30, 2015

doi:10.5539/ass.v11n19p247 URL: http://dx.doi.org/10.5539/ass.v11n19p247

\begin{abstract}
The article deals with the national-level problem of development and support of the Russian small business. It emphasizes that in this area the financial tools and methods that have been well proven in other countries are not yet implemented in full. It is concluded that the development of the theory and practical application of scientific concepts is necessary, which would allow a more active involvement of the population in this sphere of entrepreneurial business. There presented the evidence that the incomplete and incorrect statistics about the volume of resources accumulated in small business and entrepreneurs' legal ignorance result in an underestimation of the role of taxes, as the limited financial base does not allow small business to attract professionals responsible for making effective financial decisions to work. The authors' recommendation may be used during the formation of the tax system, capable to support and develop entrepreneurial activity at both the nationwide and regional levels. This system should include the development of tax measures in order to enhance the social and economic development of the Russian economy, while adapting the positive experience of foreign countries to the conditions of Russian reality.
\end{abstract}

Keywords: state, economic crisis, social function of taxes, small business, tax remissions

\section{Introduction}

At the end of XX-beginning of XXI century in developed countries the tendency of maximum government intervention in the economy was observed, the role of public authorities was visible, which using mainly regulatory functions, tried to minimally interfere in the activities of business entities, and stimulated their economic activities through appropriate financing mechanisms.

Meanwhile the taxes turned from a fiscal instrument of accumulation of market actors' money in the budget system into an economic regulator of business activity. As a consequence of this a special "economies of scale" occurred, when low taxes acted as a stimulus for labor and entrepreneurial activities and increased the tax base of the country (Pogorletsky, 2013, pp. 20-28).

In its turn, Russia's integration into the world economic community, had to go in accordance with the tendencies taking place in the developed economies, the base of which consists of the interaction of various forms of ownership and business models adequate to them, development of small business, which focuses on the realization of the social function of tax in its original ground.

The importance of the study of the social function of taxes paid by small business is determined by the need to study their intrinsic properties, methods of social orientation of mandatory payments in the context of increasing polarization of the Russian society. The transition to a market economy has provided the Russian citizens with opportunity to realize their entrepreneurial abilities in various economic sectors. This was especially evident in the sphere of small business, which due to the large number of the population involved in it both as owners and as wage workers, could partially fill the releasing niche of production of goods and services previously occupied by large-scale enterprises. 


\section{Methodology}

\subsection{Occurrence and Interpretation of the Notion of Small Business}

Transformation of state ownership form in our country, which took place at the end of the twentieth century, resulted in the deformation of the existing system of socio-economic relations and served as the basis for the formation of a fundamentally new conditions for the development of the national economy, occurrence of forms and types of business entities and principles of taxation corresponding to it.

As a result of Russia's transition to market economy the problems of prospects for further development of many large economic entities became sharp. The decrease of the volume of production, dependence on state orders, and as a result, absence of demand and noncompetitiveness of the goods produced, unstable financing and other reasons, all this eventually led to the fact that most of the city-forming economic entities of Russia turned out to be in a critical state (Glukhov \& Vavrenyuk, 2014, pp. 562-565).

The existing financial dependence of the public authorities' budgets on the receipts of obligatory payments of city-forming economic entities was the reason of the decrease and often the lack of means necessary for the development of municipal infrastructure and solution of socio-economic issues concerning the territories in which they conduct their activities.

At the same time, the transition to market economy provided Russian citizens with the opportunity to realize their entrepreneurial abilities in the various sectors of the economy. This was especially evident in the sphere of small business, which due to the large number of the population involved in it both as owners and as wage workers, could partially fill the releasing niche of production of goods and services previously occupied by large-scale enterprises.

At the same time, the very interpretation of business activity both in specialized scientific literature and other sources of information have variative nature depending on the author's point of view, and is often identified with a small business, small or individual enterprise, small businesses entity, small-scale production, small firms, companies, etc. The Federal Law of the Russian Federation dated July 2, 2010 no. 151-FZ "Concerning Microfinance Activities and Microfinance Organizations"(Federal Law of the Russian Federation, 2010, \# 151-FZ), which had come into force aggravated this variability.

Formation of market relations in its base provides for the creation of conditions for development of all forms and types of economic entities, which as the final result increases the volume of accumulated obligatory payments going into the budgets of different levels and funds, by increasing the number of taxpayers and their financial base. However, this increase is not achieved automatically; significant support for small businesses from the state is needed, as it is done in the United States. US President Barack Obama sent Congress a request for \$ 701 million for 2016 to support Small Business Administration (SBA) (Maria Contreras-Sweet, 2015).

\subsection{Role of Small Business in Economy of Different States}

Small business is of great importance not only for economy of developed economies, but also for countries with economies in a formative stage. The activities of this element of the financial system is an important factor, allowing to increase production and social infrastructure, to provide the national market with goods and services, to create additional employment.

Small businesses occupy an iconic place in American public policy debates. Numerous and diverse public policies subsidize small businesses, and political leaders of both parties routinely voice their support for the sector. At least part of this support is based on the notion that a healthy small business sector leads to innovation, jobs, and a healthy overall economy (Gale \& Brown, 2013).

One of the strongest tropes in job creation policy is that small businesses are the engines of job growth in the US economy. The US Small Business Administration (SBA) generally defines a small business as a business with less than 500 employees and less than $\$ 7$ million in average annual receipts, but there are many exceptions to the rule. Under this definition, there were 27.9 million small businesses in the US in 2010, and about 6 million of those had 1 to 499 employees in addition to the owner. These businesses accounted for 49 percent of the total employment in the US in 2010 (LewisIs, 2013).

U.S. small businesses employed about half or 55 million of the nation's private workforce in 2011. Almost all firms with employees are small. They make up 99.7 percent of all employers nationally. Firms with fewer than 100 employees have the largest share of small business employment, Table 1.

The three industries with the most small business employment were: health care \& social assistance, accommodation \& food services, and retail trade. 
Nationally, small businesses created 1,044,750 net new jobs in 2011. The biggest gain was in the smallest firm size category of 1-4 employees. The number of people who were primarily self-employed increased in 2012 . The nation's private-sector employment increased in 2013 by 2.1 percent, which was slightly below the annual average growth rate of 2.2 percent the previous year (U.S. Small Business, 2014).

Small businesses created nearly 2 million of the roughly 3 million private-sector jobs generated in 2014. More than 7 million of the 11 million jobs created during our recovery have been generated by startups and small enterprises (Maria Contreras-Sweet, 2015).

According to the European Commission there are 25 million small and medium sized businesses in the EU and they employ 95 million Europeans. This is roughly 53\% of the EU's workforce. Over $90 \%$ of these businesses are micro businesses and the average company in Europe has 5 employees (European Small Business Statistics. 2008).

The role of small and medium-sized businesses (SMEs), and their importance in the economy of the Baltic countries is also recognized as reasonably weighty, the efforts to support the competitiveness and the development of business are taken, Table 1 (Tenhunen \& Niittymaid, 2014).

Table 1. Small business in the Baltic Sea states (2013)

\begin{tabular}{|c|c|c|c|}
\hline Business & Number of enterprises & Number of employees & Value added (Billion EUR) \\
\hline \multicolumn{4}{|c|}{ Small Business in Estonia } \\
\hline Micro & 45,696 & 107.852 & 2 \\
\hline Small & 5,150 & 99,697 & 2 \\
\hline Medium sizes & 1,024 & 94,293 & 2 \\
\hline Total SMEs & 94.293 & 301.844 & 6 \\
\hline \multicolumn{4}{|c|}{ Small Business in Latvia } \\
\hline Micro & 61,787 & 143.463 & 1 \\
\hline Small & 6,899 & 140.962 & 2 \\
\hline Medium sizes & 1.484 & 135.579 & 2 \\
\hline Total SMEs & 70.172 & 420.005 & 5 \\
\hline \multicolumn{4}{|c|}{ Small Business in Lithuania } \\
\hline Micro & 95,037 & 185,648 & 1 \\
\hline Small & 10,655 & 214,024 & 2 \\
\hline Medium sizes & 2.151 & 205.876 & 3 \\
\hline Total SMEs & 107.843 & 605.548 & 6 \\
\hline
\end{tabular}

\subsection{Indicators of Small Business Development in the Russian Federation}

In its turn, the number of small business entities in the Russian Federation as of January 1, 2014 is 2063.1 thousand companies, Table 2 (Entrepreneurship. Federal State Statistics Service, 2014).

Table 2. The main indicators of the small business activity in the Russian Federation as of January 1, 2014 in units

\begin{tabular}{lllll}
\hline Indicators & $\begin{array}{l}\text { Total in national } \\
\text { economy }\end{array}$ & $\begin{array}{l}\text { Medium-sized } \\
\text { enterprises }\end{array}$ & $\begin{array}{l}\text { Small } \\
\text { business }\end{array}$ & $\begin{array}{l}\text { Other } \\
\text { entities }\end{array}$ \\
\hline $\begin{array}{l}\text { Number of enterprises (thous. } \\
\text { units) }\end{array}$ & 4843.4 & 13.7 & 2063.1 & 2766.6 \\
$\begin{array}{l}\text { Number of workers (thous. units) } \\
\text { Turnover (RUB bln) }\end{array}$ & 71391.5 & 1705.5 & 11695.7 & 57990.3 \\
\hline
\end{tabular}

Economic efficiency of small business largely depends on the position of the state both in terms of creation of conditions and different preferences provision for its development, and in terms of support during the macro scale crisis, consequences of which in this economy sector take diverse and often unresolvable forms and 
manifestations that entrepreneurs cannot solve on their own.

Today, small business in Russia is $42.6 \%$ of the total number of active economic entities, $16.4 \%$ of the economically active population are involved in it, and cash assets turnover is $21.6 \%$ of the total turnover of organizations and enterprises, Figure 1 (Federal State Statistics Service, 2014).

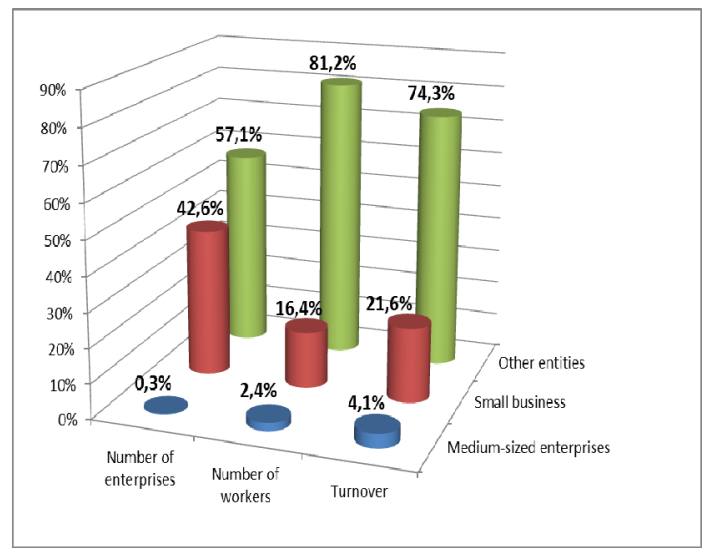

Figure 1. Comparison of the contribution of certain economic indicators of economic entities

The necessity of state support of small businesses is particularly important given the fact that its activity is related to a number of difficulties.

The institutions of bureaucracy and state support of small business can serve as an example of mutually reinforcing institutions with regard to small business. The issues concerning realization of state support of small businesses today are more difficult to resolve, if meanwhile there is no institute of bureaucracy that helps realize the need for state support.

\section{Results}

It seems to be possible to assess the effectiveness of the social orientation of taxation and completeness of its realization in different ways, however, in the author's opinion, the following criteria are the most informative. Thus, for natural persons who need social support this is the amount of free cash, remaining available after obligatory payments and the average monthly wage rate.

For small business - this is the number of participants in this type of business activity, the amount of tangible assets, number of salaried employee and their wage fund.

An indicator of the effectiveness of the tax social function will be a steady rise in the above criteria. If any of them is unchanged for a long period of time, or reduced, in this case, it is impossible to univocally assert about realization of the social tax orientation. At the same time the effect of fiscal mechanisms may be different for each group of taxpayers, depending on the current economy and the direction of economic activity of its subjects. State support of small business should be based on the development of specific measures in order to enhance the social and economic development of each particular federal subject, including in the sphere of taxation, while adapting the positive experience of foreign countries to the conditions of Russian reality.

\section{Discussion}

\subsection{Small Business Difficulties}

A considerable part of Russian small businesses use in their activity the borrowed resources as circulate assets, quite rarely creates reserve (insurance) funds for the period of crisis, and because of their lack or insufficiency, cannot exist autonomously during long crises. As a consequence, it is necessary to note the presence of risks of small business, its high dependence on changes in the course of domestic and foreign economic policy of the state, the long period of return on investment, as well as their lack, difficulty to legally attract financial resources.

Small business, being a special case of entrepreneurial activity, is characterized by a higher degree of risk, innovation, initiative, but it has a lower degree of independence, the desire to form informal relationships and structures, latency, to go to the shadow economy sector.

The ability to unite certain factors of production in a particular situation efficiently allows small businesses to 
combine them in new forms of economic activity and in participation in the most profitable sectors of the economy, to respond quickly to changes in the external market conjuncture.

The crisis phenomena that occurred in 2014, on the scale of both global and national economies, left their mark on the socio-economic development of the Russian Federation, resulted in decrease of business and production activity of small business, had influence on the population income reduction, the number of taxpayers and, consequently, on the volume of tax revenues to the budgets of different levels. Reduction of volumes and areas of production of goods and services, decrease of investment activity of entrepreneurs, increase of the number of non-payments for goods produced and services rendered, a reduction of workers, and move into shadow economy sector, etc. took place.

Uncertainty of modern tax policy and its dependence on crisis situations is typical for developed countries.

Raymond J. Keating отмечает, что in recent years, the tax story at the federal level has been uniformly negative for entrepreneurs, investors, workers, and the economy in general. Small business owners and entrepreneurs face great uncertainty as to expiring provisions. Many measures remain temporary, or are renewed on an annual basis. Businesses cannot function efficiently or make sound investment decisions when the federal tax system is forever in flux (Raymond, 2014).

\subsection{Role of State in Support of Small Business}

As the final result, these factors in their totality should lead to the public authorities' understanding of the importance of the transition from the current unilateral practice of realization of the fiscal tax function as the principal income source of the budget system, to the social one, initially enabling citizens to increase their business activity. The effectiveness of its development, particularly in the sphere of small business should be accompanied by a simplification and stability of taxation, and its social orientation will reduce the negative effects of the financial crisis on the national economy.

Here the consolidating role of the state should appear, through the realization of socially oriented tax policy, the essence of which is to support small businesses, especially in the period of crisis situation in the economy. Promotion of small business can be performed, including non-tax methods in the form of concessional lending, various support programs and rendering advisory services, and stimulation of development in the priority sectors of the national economy, etc.

Gorsky K. V. emphasizes that sectoral tax burden should be aligned only through the creation of equal conditions of taxation for all business entities, but additional benefits cannot be given to "deserve" productions. Ultimately, it will provide a uniform tax burden on all sectors of the economy. If the consequences of equal taxation affect the state of certain types of activities in various ways, the reason for this should be searched in impact of other market factors rather than in taxes. You should not interfere with market laws with taxes unless it is absolutely necessary (Gorsky, 2004, p. 23).

The economic substance of tax incentives consists in the fact that taxpayers were interested to develop their activities in those areas, which met the needs of society. As for the stimulation of investment and innovative activities of enterprises, tax remissions should primarily provide increased financial investment in this sphere by non-state economic entities (Mitrofanov \& Onikova, 2013, p. 136).

\subsection{Development of the Population Business Activity}

One of the main tasks of the Russian state especially under the conditions of increasing macroeconomic crisis should not only be the social orientation of small business taxation, aimed both on its support, and to create incentives for its owners to invest in the keep and increase production volumes, in order to substitute import by domestic goods.

The state role in creating the conditions for the development of small businesses shall consist in the formation of a favorable investment and tax climate, simplification of the tax legislation, granting of the "cheap" borrowed money resources, provision of various types of consulting support, community and balance of the state's and entrepreneurs' interests. As the final result, this should lead to qualitative changes in the small business, increase of the owners' interest in its legalization and further development, social orientation and stability of the reforms, expansion of production, increase of the number of wage workers - the taxpayers and as a result increase of volumes of obligatory payments, and creating an attractive image of the region.

Creation of favorable conditions in the region for various types of business activity, means choosing the jurisdiction of the corresponding territory by a taxpayer for business setting up and running, i.e. it leads to increase of the number of taxpayers. 
To some extent this is related to the Ch. Tiebout's hypothesis, according to which, the taxpayers, as the primery consumers of public goods, have a choice both of a place of residence, which is under the authority of a particular jurisdiction, and of the corresponding list of services provided for taxes paid.

At the same time for the territories with lower tax rates and a larger list of provided public goods and services, in comparison with other populated localities, there is the possibility of higher prices for rent or purchase of real estate, plots of land, etc. (Epple, Zelenitz, \& Visscher, 1978).

Reaction mobility of population business activity to the business conduct conditions, makes regional public authorities pay attention to improving the quality of tax administration, aimed at increase of investment and innovation potential of the territories.

According to Burov V. Y. modern Russian small business is characterized by social orientation, which is evidenced by its role and contribution to the social development of the regions: increase of job creation, increase of the population income level, creation of the middle class (Burov, 2014, p. 105).

\subsection{Value of Taxes, Paid by Small Business}

The standard structure of taxation of income and property of small business entities may involve, among others, minimization of tax costs both of taxpayers and the state associated with the collection of these taxes. This, in its turn, requires the introduction of special taxation rules with regard to such entities (Bykov, 2013, p. 22).

Special mention may go to the interconnection and interdependence between the personal income tax (PIT) paid by workers employed in the sphere of small business, the taxes paid by its owners and their influence on the development of social and economic infrastructure of the region. PIT both of business owners and wage workers can act as a characteristic not only of their personal well-being, but also of the private household life, the members of which they are.

In its turn, the taxes paid by small business, are an indicator of ongoing regional social and economic policy, form the attractiveness of the territory for potential investors in terms of the development of the various types of business activity and the realization of various projects. Under the conditions of the national economy reforming and its competitiveness increasing it is necessary to socialize small business taxation, to determine its development prospects and for this purpose to increase motivation both of its owners and wage employees. Therefore, the efficiency of market reforms and the bailout of the national economy consist not only in the realization of full fiscal function of taxes by public authorities, but also in increase of the socio-economic importance of small business in the development of the entities of the Russian Federation.

Under the current conditions of market relations, when much considerable part of resources is privately owned, and the public authorities act as a regulator between centralized and decentralized sectors of the financial system, the result of the effective functioning of a socially oriented tax policy should be an increase of the number of small business enterprises, income both of their owners and people working in this sphere.

Strengthening of the role of the state does not provide for its direct intervention in the distribution processes taking place in the economy, strengthening the regulation of economic relations between the basic elements of the financial system, the predominance of state property in its overall structure.

In its most common form it should be manifested in reforming of the economy sphere, tariff regulation, regulation of external economic relations, management of fiscal, tax, investment, credit policy, etc..

\subsection{Preferences and Benefits, Provided to Small Business in the Russian Federation}

This is not to say that the state does not provide Russian small business with tax benefits. In the modern Russian tax legislation certain tax preferences in the form of special tax regimes that reduce the tax burden and simplify business accounting are provided to small businesses.

However, the effectiveness of their results is evened by the general economic instability and uncertainty, inattention of the public authorities to the public and social importance of this sphere of the business activity of citizens. In addition, the full realization of the stimulating potential of taxation for small business is prevented by combination of some objective and subjective factors, which both the state and the small business entities themselves have.

The "Main directions of tax policy of the Russian Federation for 2015 and the planning period of 2016 and 2017", approved by the Government of the Russian Federation on July 1, 2014, provides for measures to stimulate the development of small business established from 1 January 2015 till 31 December 2018.

In particular the regions of the Russian Federation will be entitled to establish "tax holidays" in the form of 0 
percent tax rate for the entrepreneurs registered first time, which changed to the simplified tax system and the patent system of taxation and operating in the industrial, social and scientific spheres, (draft guidelines of tax policy of the Russian Federation for 2015 and the planning period of 2016 and 2017, 2015).

According to Bobrova A. V. now the state policy in the sphere of small business is declared as its accelerated development by increasing of the targeted funds flow from the budgets of different levels and widening the scope of activities. Unfortunately, the facts show that there are no dramatic changes in this area. In addition, the Tax Code of the Russian Federation constantly changes the list of the types of activities, which does not allows the territories to effectively rely on the taxes from small businesses (Bobrova, 2012, pp. 91-92).

On the other hand, providing payers with tax preferences and reducing the overall level of tax burden, the state expects the civilized behavior of business entities - the legalization of business, the use of the resources released due to reduction of the tax burden for social and investment development of the regions.

In terms of small business support on January 27, 2015 the Government of the Russian Federation approved the plan of primary measures for sustainable development of economy and social stability in 2015 (anti-crisis plan), which provides:

- allocation of additional funds to the Fund in the amount of 2 billion rubles for grants to small innovative enterprises for the financial support of innovative projects having prospects of commercialization (the "Commercialization" competition);

- two fold increase of the limit values of proceeds from sales of goods (works, services) to classify the economic entities into the category of small business (from 400 to 800 million rubles).

In this regard, the Fund for the Promotion of the Development of Small Businesses in the Sphere of Science and Technology decided to increase the maximum amount of the grant on the "Commercialization" competition from 10 to 15 million rubles (Fund for the Promotion of the Development of Small Businesses in the Sphere of Science and Technology, 2015).

Not surprisingly, however, the economic issues surrounding small businesses and innovation are more complex and nuanced than any iconic designation would suggest. At the core of these issues are the questions of whether and how public policies should subsidize small businesses. On the one hand, economic theory prescribes that well-designed tax and spending programs, in the absence of externalities or public goods, should be neutral among types of investments and forms of business organization, leaving a free market to allocate resources efficiently between small versus large business. On the other hand, small business owners may face special barriers to entry or to firm expansion and many people assert that the small business sector is our principal engine of jobs, growth, and innovation (Gale \& Brown, 2013).

\section{Social Function of Small Business}

\subsection{Social Implication of Small Business in the National Economy}

The effective use of the involved financial resources, the reduction of the process and functional expenses in the organization of the revenue body work, strengthening of the tax social function, which allows linking the strategic targets of the country development with the mechanisms of the tax impact by the state, is needed. The end result of tax stimulation of investment and production activity of small business will be its social and public responsibility.

Small business owners, interested in assurance and increase of their income, creation of jobs, payment of wages to workers, obligatory payments to the budgets of different levels and funds, form the profitable sources of the public authorities and other legal entities and private persons. Thus the material basis for execution by the state of the main socially significant tasks of Russian society is created.

This interrelation of government and business by means of the initially oriented social function of taxes enables to create conditions to stimulate economic entities of all forms and types of property to their development, maintenance of an appropriate regional infrastructure, improvement of the population welfare.

In comparison with large enterprises small business has certain advantages:

- Quick adaptation to economic conditions;

- Efficiency of the making and implementation of decision;

- Minimization of administrative expensive;

- Low need for initial capital; 
- High efficiency of financial management.

Due to its small size, small business enables to provide technological, production and managerial mobility, allowing quick response to changes of market structure, introduction of important innovations, implementation of effective management, more quick response to requirements of market and consumer demand.

The social function of small enterprises, which consists in its ability to engage the unemployed citizens in large volumes, thereby reducing social tensions and the unemployment rate, earns special attention. In this regard, the development of small business - is an important direction of well-weighed state policy, which should be aimed at supporting and encouraging business activity of the population.

\subsection{Small Business Support Models}

Any form of state support for small businesses is realized in the national wealth redistribution processes, in which two basic models of its redistribution while realizing various types of small businesses support programs can be specify.

The first model provides for the mobilization of the part of the value produced by small business in the form of taxes to the budgets of different levels, and its subsequent distribution in the form of grants, subsidies to small business entities.

The second model involves weakening the tax burden for small business in the form of various kinds of benefits, privileges, preferences; tax holidays, low tax rates, etc.

However, it is always useful to remember that the marginal utility of income money unit, originally left at the small business entity will be more important than marginal utility of attracted value due to various types of financial support funds.

In the first model, the bodies of state and local authority essentially open the field of possible entrepreneurship, put the participants in more equal positions, give them more freedom, reduce corruption component while distributing various grants.

The second model in a greater degree allows the selection of grant recipients, but this does not exclude the fact that a greater number of small business entities is able to generate and realize breakthrough innovative ideas in business. Finally, the tax breaks for more number of small business entities, rather than for their individual part, chosen as a result of selection, can simultaneously realize social function to a greater extent.

The provision of benefits and preferences for small business, bypassing the redistribution mechanism, allows these entities of the national economy to "stay afloat" especially in the period of crisis situations, to realize its social function in different aspects. In the period of economic crisis, big business has more opportunities for saving, because it uses completely different conditions for the organization and support of its activities (simpler access to the borrowed resources, the possibility of using its position in the government, etc.).

Therefore, the mechanism of universal "break" may work more effectively in the current situation. The question is about kind of "smoothing" of social tension as a rule growing in such situations rather than about the benefits of the budget. In addition, the "soft" taxation - is a delicate instrument for national security (of course, not the only one).

The model of targeted financial assistance through the redistribution of public resources is usually used when the crisis was over and the state faces the problem of identifying of economic growth points, breakthrough directions of the economic development.

The use of a selective approach to support will enable only some, not all small business entities to be among its beneficiaries - those who will be able act according to the stated priorities. There is a risk that the entity that is subject to profits will take the opportunity to attract additional financial resources, will get the targeted assistance under them in the form of "grants", but will not reach the designated indicators.

\subsection{Small Business, as a Form of the Population Business Activity Realization}

An important aspect of the considered problem is the ambiguousness of the results of realization of a small businesses support model, and therefore the realization of the social function of its taxes.

If this problem is considered in the concept of the of economic growth theory, the model of selective approach to small businesses may be more effective, because it is aimed at supporting in a form of grants of the most effective investment projects.

When the question is about the decreasing trend of economic growth, then the problem of creating conditions for the elementary survival of the Institute for Small Business comes to the fore. In this case, the model of financial 
resources allocation among the much larger number of small business entities proves its efficiency.

This is realized in the form of easing of the tax burden for all the participants, giving opportunity to realize the social function of the tax on small business. In this case, the methodological approaches to the assessment of taxation model efficiency should be considered with the view of time, i.e., subspecietemporis, rather than with the view of eternity - subspecieeternitatis, as B. Spinoza wrote about this methodological approach. The result of Pareto-efficiency of the same process of support of small business entities will show diametrically opposite results in appropriate spatial and temporal conditions.

Small business is the most dynamic form of realization of the population business activity, which allows citizens to realize their business and creative potential. The development of such enterprises is a necessary condition for the formation of a competitive economic environment that allows counteracting the monopoly of large integrated business structures in various sectors of the economy.

This concerns many directions of the national economy, in which business activity of population was able to solve the problems of:

- Creating a middle class of owners, which is the basis of economic stability in developed countries;

- Employment of different categories of people who for some reason could not initially find themselves in conditions of market relations;

- Formation of profitable sources of budgets of different levels of public authority and non-budgetary funds (NBF), by increasing of the number of payers of obligatory payments;

- Creating a competitive environment in the process of production and filling of the national market with goods and services;

- Accumulation of significant volumes of financial, production, raw materials, labor resources used ineffectively;

- Raising the material living standard of population, etc.

\section{Conclusions}

The development of an economy based on private property is possible due to increase of the small business entities number, the volume of their material assets and the number of people involved in the labor activity. In this regard, there is urgent need to build the state partnership relations represented by tax authorities and taxpayers, taking into account the specifics of national financial policies.

Analysis of the condition of the Russian taxation system in terms of its social orientation has shown that there are gaps in the scientific substantiation of the role of the tax social function related to the priority and the predominance of its fiscal function. The current character of tax relationships results in distortion of the interrelation between the functions of taxes, dominance of their fiscal orientation.

Thus, based on the above, the Russian taxation system sets a task to move to its social orientation, in the process of taxes collection in order to support the business activity of citizens involved in the sphere of small business, aimed at improving the development efficiency of the entities of the Russian Federation.

\section{References}

Bobrov, A. V. (2012). The tax burden in business. Vestnik of SUSU, 22(281), 90-94.

Burov, V. Y. (2014). Small business in the system of economic security. Proceedings of the Irkutsk State Economic Academy (Baikal State University of Economics and Law), 5(97), 101-108.

Bykov, S. S. (2013). Classification of tax remissions as a condition and stage of assessment of their effectiveness. Proceedings of the Irkutsk State Economic Academy (Baikal State University of Economics and Law), 5(91), 20-26.

Contreras-Sweet, M. (2015). Fiscally Responsible SBA Has Strong Case for FY16 Budget. Retrieved January 23, 2015, from https://www.sba.gov/blogs/fiscally-responsible-sba-has-strong-case-fy16-budget

Draft Guidelines of the tax policy of the Russian Federation for 2015 and the planning period of 2016 and 2017. Retrieved January 23, 2015, from http://sfr.bujet.ru/

Entrepreneurship: Federal State Statistics Service. Retrieved January 23, 2015, from http://www.gks.ru/wps/ wcm/connect/rosstat_main/rosstat/ru/statistics/enterprise/

Epple, D., Zelenitz, A., \& Visscher, M. (1978). A Search for Testable Implications of the Tie bout Hypothesis. The Journal of Political Economy, 86(3), 405-425. http://dx.doi.org/10.1086/260679 
European Small Business Statistics. (2008). Retrieved January 21, 2015, from http://www.smallbizlabs.com/ 2008/08/european-small.html

Federal Law of the Russian Federation dated July 2, 2010 \# 151-FZ (Concerning Microfinance Activities and Microfinance Organizations). Retrieved January 22, 2015, from http://base.garant.ru/12176839

Federal State Statistics Service. Retrieved January 24, 2015, from http://www.gks.ru/wps/wcm/connect/rosstat main/rosstat/ru/statistics/enterprise/reform/\#

Fund for the Promotion of the Development of Small Businesses in the Sphere of Science and Technology. The size of the grant on "Commercialization" competition has been increased to 15 million rubles. Retrieved January 29, 2015, from http://www.fasie.ru/obyavleniya/9-obyavleniya-dlya-zayavitelej/1773-razmer-granta -po-konkursu-kommertsializatsiya-uvelichen-do-15-mln-rublej

Gale, W., \& Brown, S. (2013). Small business, innovation and tax policy: A review. Retrieved February 8, 2015, from http://www.taxpolicycenter.org/UploadedPDF/1001675-Small-Business-Innovation-and-Tax-Policy-A -Review.pdf

Glukhov, V. V., \& Vavrenyuk, V. G. (2014). The role of high education institutions in modern Russian metropolis development using as an example Vladivostok city. Life Science Journal, 11(12), 562-565.

Gorsky, K. V. (2004). Some parameters of tax reform. Finances, 2, 22-26.

Keating, R. J. (2014). Small Business Tax Index 2014: Best to Worst State Tax Systems for Entrepreneurship and Small Business. Retrieved January 23, 2015, from http://www.sbecouncil.org/wp-content/uploads/2014/04/ BTI2014Final.pdf

Lewisis, W. D. (2013). Small Business or Are New Companies the Engine of Job Growth in the US? Retrieved February 12, 2015, from http://www.glbperspective.com/business/finance/is-small-business-or-are-newcompanies-the-engine-of-job-growth-in-the-us/

Mitrofanov, I., \& Novikova, E. V. (2013). Differentiation of tax remissions as the economic and management conditions to stimulate investment and innovation activity in enterprises (domestic and foreign experience). Tax and Finance Law, 3, 135-142.

Pogorletsky, A. I. (2013). Individual income taxation in the world and Russian practice: Current tendencies and prospects. Business inform, 11, 20-28.

Tenhunen, L., \& Niittymaid, S. (2014). Small Business Act in Practice in the Baltic Sea States. Hameenlmna (p. 43). Retrieved January 24, 2015, from http://portal.hamk.fi/portal/pls/portal/!PORTAL.wwpob_page. show? docname $=13515629$.PDF

U. S. Small Business Administration Advocacy: The voice of small business in government. (2014). Retrieved January 22, 2015, from https://www.sba.gov/sites/default/files/files/UnitedStates13\%281\%29.pdf

\section{Copyrights}

Copyright for this article is retained by the author(s), with first publication rights granted to the journal.

This is an open-access article distributed under the terms and conditions of the Creative Commons Attribution license (http://creativecommons.org/licenses/by/3.0/). 